DOI: 10.31392/NPU-nc.series14.2019.27.17

УДК: 37.011 .3 - 051: 7 [: 124. 5 - 047. 37

Ху Тінтін

\title{
Художньо-аксіологічна культура вчителя мистецтва як предмет дослідження
}

\begin{abstract}
У статті розглянуто проблему художньо-аксіологічної культури вчителя музичного мистецтва, визначено іï сутність, зміст, структурні компоненти. Доведено, що художньо-аксіологічна культура вчителя мистецтва $є$ особистісним інтегративним утворенням, що характеризується високим рівнем професійної майстерності на основі глибоко вмотивованого ціннісного ставлення до мистецтва та педагогічної діяльності. Для художньо-аксіологічної культури вчителя мистецтва притаманним $\epsilon$ наявність активної позиції щодо критичного осмислення, відбору художніх цінностей та їх трансляції в середовищі учнівської молоді. Структура художньо-аксіологічної культури вчителя музичного мистецтва включає мотиваційно-пізнавальний, аналітико-аргументувальний, інтерпретаційно-творчий, комунікативно-трансляційний, рефлексивно-результативний компоненти.
\end{abstract}

Ключові слова: учитель музичного мистецтва; художньо-аксіологічна культура; педагогічна діяльність.

Актуальність дослідження. Нові вимоги до рівня художньо-педагогічної діяльності учителя музичного мистецтва зумовлено тією визначною роллю, що відводить йому сучасне суспільство у розвитку культури, мистецького розвитку учнівської молоді. В системі професійних компетентностей педагога-музиканта в сучасних умовах чи не на перший план виходить проблема формування ціннісного ставлення учителя як до художньої культури у всьому розмаїтті їі проявів, так і до критично-аналітичного осягнення наслідків педагогічної діяльності. Тільки той вчитель, у якого сформовано ціннісні орієнтири у сфері мистецтва і педагогіки, зможе на сучасному рівні професійно здійснювати музичне навчання учнівської молоді.

Необхідність внесення суттєвих коректив до підготовки вчителя мистецтва зумовлені потребами формування високих ціннісних орієнтирів учнів в художній культурі, розкриття їхнього гуманістичного потенціалу, ціннісного ставлення до життя. В цьому контексті актуалізується проблема визначення сутності, змісту та структури художньо-аксіологічної культури учителя мистецтва як необхідної складової його готовності до професійної діяльності.

Проблема аксіологічної спрямованості професійної підготовки майбутнього педагога дістала плідного розгляду у роботах сучасних авторів $[2 ; 5 ; 6 ; 12 ; 10 ; 13]$. Культурологічні тенденції впливу аксіологічного підходу досліджено у контексті становлення особистості [4; 9; 14; 17]. До естетичних вимірів ціннісного ставлення до мистецтва звертались А. Гулига, I. Андреєва [1]. Науковці переважно зосереджують увагу на виявленні розвивального потенціалу естетичного ставлення до мистецтва, визначають залежність між ціннісними орієнтаціями особистості і iї гуманістичним потенціалом, підкреслюють значення аксіологічного контексту становлення педагога. Суттєвого значення набуває дослідження питань ціннісного спрямування розвитку особистості [8].

Проблеми аксіології мистецтва привертають увагу сучасних дослідників в галузі мистецтвознавства [7; 11; 15]. Стверджується, що аксіологічне спрямування навчання відкриває можливості творчої активізації навчання $[10 ; 16 ; 17]$.

Водночас проблема художньо-аксіологічної культури учителя мистецтва як складової його професійної компетентності не знайшла наукового розгляду.

Мета статті - уточнити сутність і зміст поняття "художньо-аксіологічна культура вчителя мистецтва", визначити її структуру.

Виклад основного матеріалу. Під художньо-аксіологічною культурою вчителя мистецтва ми розуміємо інтегративне утворення особистості, що характеризується високим рівнем професійної майстерності на основі глибоко вмотивованого ціннісного ставлення до 
мистецтва та педагогічної діяльності. Для художньо-аксіологічної культури вчителя мистецтва притаманним $\epsilon$ наявність активної позиції щодо відбору художніх цінностей та їх трансляції в середовищі учнівської молоді.

Художньо-аксіологічна культура як особистісний і соціальний феномен характеризується неоднозначністю, складністю, виступає однією із складових професійної культури вчителя. Висуваючи нові вимоги до підготовки вчителя мистецтва, сучасне суспільство хоче бачити в ньому не тільки виконавця певних професійних функцій, а й насамперед високо розвинену духовну особистість, творчі можливості якої зумовлені здатністю критично-аналітичного осмислення мистецтва та педагогічної реальності.

Художньо-аксіологічна культура вчителя виступає міждисциплінарним феноменом, змістові характеристики якого найповніше виявляються при розгляді структурних компонентів.

Структура художньо-аксіологічної культури вчителя музичного мистецтва включає мотиваційно-пізнавальний, аналітико-аргументувальний, інтерпретаційно-творчий, комунікативно-трансляційний, рефлексивно-результативний компоненти.

Мотиваційно-пізнавальний компонент визначається прагненням учителя музичного мистецтва до оволодіння аксіологічними підходами у пізнанні мистецтва, у розвитку власної художньо-аксіологічної культури; бажанням розширити мистецький тезаурус, накопичити якомога більше художньо-образних вражень; усвідомленістю виховного потенціалу мистецтва та його значення у художньому розвитку школярів. Мотиваційно-пізнавальний компонент художньо-аксіологічної культури вчителя характеризується також осягненням ролі мистецтва у розвитку сучасної культури суспільства, готовністю до засвоєння педагогічних підходів у формуванні художньо-оцінювальних орієнтирів учнівської молоді. Йдеться про оцінювальне пізнання, про таке сприймання, де пізнання художньої сутності творів мистецтва йде пліч-о-пліч із його оцінюванням вчителем. Важливо, щоб учитель музики був спроможний не лише до активного переживання, а й до суб'єктивноіндивідуального тлумачення образного змісту твору. Мотиваційно-пізнавальний компонент художньо-аксіологічної культури орієнтує не на нейтральне споглядання художньої інформації, а на оцінне ставлення до зображуваного, вираженого, відтвореного у мистецьких образах. Пізнаючи художній твір, його образну сутність, учитель з розвиненою художньоаксіогічною культурою одночасно дає їм певне тлумачення у відповідності зі ступенем розвитку власної художньо-аксіологічної культури. При цьому важливо, щоб естетичні орієнтири і норми пізнання мистецтва вчителем усвідомлювались як органічна складова його педагогічної діяльності.

Аналітико-аргументувальний компонент художньо-аксіологічної культури вчителя музичного мистецтва характеризується здатністю до глибокого осмислення художнього змісту і форми мистецьких творів, аргументованого усвідомлення та роз'яснення своєї художньої позиції. Музично-аналітичні уміння - невід'ємна ознака художньо-аксіологічної культури вчителя, характер професійної діяльності якого потребує усвідомлення як образного змісту музики, так і виразних особливостей форми втілення цього змісту. Важливим для учителя $є$ уявлення щодо мети аналітичного розбору твору, щодо необхідності виконавського донесення до юних слухачів композиторського задуму в його цілісності, забезпечити естетичне переживання, емоційне заглиблення дітей у музику. Аналітико- аргументувальний компонент художньо-аксіологічної культури вчителя передбачає його здатність спрямувати сприймання дітей таким чином, щоб образність твору постала в їхній свідомості у єдності із естетичним переживанням засобів її досягнення, із розкриттям виражального змісту художніх деталей твору. Аналітичні уміння вчителя характеризуються здатністю спрямувати увагу школярів при слуханні музики на процес розгортання образного змісту, на динаміку руху як іманентну ознаку музичного мистецтва. У процесі аналізу учитель має вичленити головні, провідні моменти смислового наповнення образу, найяскравіші його особливості. 
Суттєвого значення набуває аналіз твору у формуванні здатності учителя до його аргументованої оцінки. Виявлення та усвідомлення власної художньої оцінки твору має знайти підтвердження у логічній і послідовній ії аргументації. Висловити своє враження про музику у формі «подобається - не подобається» порівняно легко. Значно складніше знайти підтвердження своєї думки в аналітичному осмисленні характерних ознак змісту, композиційної структури твору, в деталях його форми, в доказовому аргументуванні їх естетичних переваг і вад. Художньо-аксіологічна культура вчителя має стояти на сторожі спрощення аналізу, підкреслення неважливих ознак, перевантаження пояснень асоціаціями, далекими від образного змісту даного твору.

Інтерпретаційно-творчий компонент художньо-аксіологічної культури зорієнтовано на виявлення вчителем музичного мистецтва свого оцінного ставлення до твору у процесі його інтерпретації, яка, в свою чергу, має характеризуватись оригінальністю, самобутністю, ініціативністю підходу до виконавського тлумачення образного змісту музики.

Інтерпретація музики - процес взаємодії виконавця з композитором. Дослідники [7; 16] відмічають творчий характер цієї взаємодії. Перед інтерпретатором постає завдання - не тільки глибоко усвідомити і розкрити авторські задуми, а й відтворити у виконанні власне ставлення до музики, особливості свого ії переживання і оцінювання. Виконання музики, що не викликає емоційно-оцінної реакції у ії інтерпретатора, навряд чи зможе захопити слухачів, особливо, коли йдеться про поки що незрілі художні смаки і уподобання учнівської молоді. Через те для учителя-виконавця вкрай необхідною $є$ яскрава оцінна позиція, відчутно представлена у виконавському процесі. Нейтральне, байдуже виконання несумісне iз представленням музичного твору в дитячій аудиторії. Художньо-аксіологічна культура вчителя зумовлює виразність інтерпретації вчителя, окреслюючи моменти доречного, відповідно-тактовного оцінного ставлення виконавця до музичного твору. При цьому виникає питання щодо взаємодії оцінного і творчо-ініціативного підходів до тлумачення музичного тексту. Ми вважаємо, що творчість як відтворення індивідуальності інтерпретатора $\epsilon$ залежною від його ставлення до музики. Інтерпретація - це виявлення ставлення до музики через творче іiі прочитання. Оригінальність, неповторність трактовки музичного твору, iї творча наповненість зумовлюється значною мірою силою емоційного враження від музики. Якщо ж твір не викликає у виконавця непідробного захоплення, щирого естетичного схвалення, навряд чи він зможе створити виразну інтерпретаторську концепцію, знайти творчі прийоми демонстрації твору у слухацькій аудиторії. Отже, оцінювання і творчість в мистецтві музичної інтерпретації йдуть поруч, стимулюючи і впливаючи одне на одного. Розуміючи інтерпретацію як творчий діалог між композитором і виконавцем, наголосимо на суттєвій ролі інтерпретаційно-творчої складової в структурі художньо-аксіологічної культури особистості.

Рефлексивно-результативний компонент спрямовує оцінну свідомість учителя музичного мистецтва на самоспоглядання, самоцензурування власної мистецької і педагогічної діяльності, виражає здатність до виповнення власних дій ціннісним сенсом.

Проблема рефлексії не є новою. Вчені пов'язують рефлексію $з$ такими категоріями, як самопізнання, самоспостереження, самооцінка. Підкреслюється, що саме завдяки рефлексії, людина вступає в “ особистісні стосунки " зі світом, пізнаючи й оцінюючи його [2; 6]. Рефлексія виражає внутрішній світ людини [3]. Рефлексія виступає вищим рівнем педагогічного мислення,його оцінювальним ядром, стимулом до переходу на інший щабель професійного розвитку.

Розглядаючи рефлексивно-результативний компонент структури художньо-аксіологічної культури вчителя, підкреслимо, що дія його пронизує різні грані професійної діяльності - і сприймання, i уяву, i творчість. Оцінюючи результати власної діяльності, досягнень i прорахунків у естетичному розвитку учнів, учитель отримує можливість аргументованої корекції всіх актів мистецької педагогічної діяльності від ії пізнання до перетворення. Саме 
рефлексивно-результативна складова виступає стрижневою у системі взаємодії всіх визначених компонентів.

Висновки. В результаті дослідження ми дійшли висновку, що саме культурологічні виміри аксіології у особистісному трансформуванні можуть суттєво розширити межі освоєння студентами як фахового музичного навчання, так і педагогічної майстерності. Структуру художньо-аксіологічної культури визначаємо як цілісну єдність мотиваційнопізнавального, аналітико-аргументувального, інтерпретаційно-творчого, комунікативнотрансляційного та рефлексивно-результативного компонентів. Підкреслимо, що подальший пошук шляхів формування художньо-аксіологічної культури у майбутніх учителів музичного мистецтва має бути зорієнтований на системне забезпечення здатності студентів до аналітичного пізнання професійної діяльності, до аргументованого аналізу, до рефлексивного тлумачення музично-виконавських і педагогічних дій, а також мотиваційного творчого ставлення до оцінювальної діяльності як чинника досягнення професійної майстерності.

\section{Література}

1. Гулыга А. В., Андреева И. С. Эстетика в свете аксиологии. 50 лет на Волхонке. СПб.: Алетейя, 2000. $445 \mathrm{c}$.

2. Гущина Н. А. Аксиологические аспекты отечественного образования как фактор формирования профессионально-ценностных ориентаций будущего учителя: дис. ... канд. пед. наук. Калуга, 2004. 188 с.

3. Елагина В. С. Аксиологический подход к развитию индивидуальности личности студента [Электронный pecypc]. Режим доступа: http://cyberleninka.ru/aksiologicgeskiy-podhod-k-razvitiyuindividualnosti-lichnostistudenta.pdf.

4. Ерасов Б. С. Социальная культурология: учебник для вузов. М. : Аспект-Пресс, 2000. - 591 с.

5. Есипова Е. В. Культурологические основы формирования ценностного отношения к педагогической профессии: автореф. дис. ... канд. пед. наук. Ростов-на-Дону, 2007. 22 с.

6. Калюжная Т. Г. Аксиологический подход в системе профессионально-педагогической подготовки будущего учителя [Электронный ресурс]. Режим доступа: http://lib.iitta.gov.ua/5180/1/

7. Мухин А. С. Аксиология искусства: к вопросу о базовых принципах. Studia culturae: Альманах кафедры культурологии и Центра изучения культуры философского факультета СПбГУ; Выпуск 13 Санкт-Петербург : Санкт-Петербургское философское общество, 2011. С. 61-76.

8. Марчук М. Г. Ціннісні потенції знання. Чернівці : Рута, 2001. 319 с.

9. Плюснин Ю. М. Два полюса ценностного развития личности. Гуманитарные науки в Сибири. 1995. № 2. C. 33-40.

10. Сластенин В. А. Введение в педагогическую аксиологию: [учеб. помощь для студ. высш. пед. учеб. заведений]. М. : Издательский центр "Академия", 2003. 192 с.

11. Смотрицкий Е. Ю. Схемы по философии: Этика. Аксиология. Мировоззрение. Днепропетровск : Пороги, 2003. 22 с.

12. Ткачова Н. О. Аксіологічний підхід до організації педагогічного процесу в загальноосвітньому навчальному закладі: [монографія]. Луганськ: ЛНПУ імені Т.Г. Шевченка; Х. : Видавництво "Каравелла", 2006. 300 с.

13. Ярошенко А. О. Ціннісний дискурс освіти: [монографія]. К. : НПУ імені М. П. Драгоманова, 2004. $156 \mathrm{c}$.

14. Kiper H. Interkulturelle Erziehung in Praxis und Theorie. Saarbrücken, 1995.-320 S.

15. Kluckhohn C. Values and Value Orientation in the Theory of Actions. Toward general Theory of Action. Cambridge. 1951. 411 p.

16. Linden B. Die Hochschule als multikulturelles Zentrum. Bildung und Wissenschaft. 1996. №2. S. 16-17.

17. Pankiv L. Formation of Artstic Orientations of Senior Pupils in the Context of Modern Methodological Approaches. Intellectual Archive, Volume 8, Number 3. - July - September 2019 (Canada). - P.198-206 // DOI 10.32370/IA_2019_09_23 


\section{Про автора:}

Ху Тінтін, аспірантка факультету мистецтв імені Анатолія Авдієвського Національного педагогічного університету імені М.П.Драгоманова; ORCID: 0000-0002-2785-671X, hu.tintin2020@gmail.com

\section{Art-axiological culture of art teacher as a subject of research}

Hu Tinting

The relevance of the study motivated by the social importance of the artistic and axiological culture of the teacher in the artistic development of the students, the formation of which is an important factor in the renewal of music and pedagogical education.

The analysis of recent studies shows that the problem of axiological orientation of future teacher's professional training has received some consideration. The works of contemporary authors investigate the aesthetic dimensions of the value attitude to art, the relationship between the value orientations of the individual and his humanistic potential, the influence of the axiological direction of learning on his creative activation. At the same time, the problem of the artistic-axiological culture of the art teacher as a component of his professional competence has not found scientific consideration.

The purpose of the article is to determine the essence, content, structure of the art-axiological culture of the art teacher.

Research methods included a critical comprehension of the scientific literature; comparison; structuring; modeling; theoretical analysis and generalization of conclusions.

Presenting main material. The artistic and axiological culture of the art teacher is a personal integrative education characterized by a high level of professional skill based on a deeply motivated value attitude to art and pedagogical activity. The structure of the artistic and axiological culture of a teacher of music art includes a number of components. The motivational and cognitive component of artistic and axiological culture orients the teacher to evaluate attitudes toward the depicted, expressed, and reproduced in artistic images. Knowing the work of art, its figurative essence, the teacher at the same time gives them a certain interpretation. At the same time, aesthetic landmarks perceived as an organic component of pedagogical activity. The analytic and argumentative component characterizes the teacher's ability to grasp deeply the artistic content and form of the works of art, the reasoned awareness and clarification of his artistic position. It is important for the teacher to understand the purpose of analytical analysis of the work as a means of ensuring the aesthetic experience of children. The interpretive-creative component focused on the teacher's identification of his evaluative attitude in the process of interpretation of a work of art. The task of the interpreter-teacher is to not only deeply understand and disclose the concept of the composer, but also to reproduce in performance his own attitude towards music. The reflexive-effective component directs the evaluative consciousness of the music art teacher to self-observation, to censorship of his own artistic and pedagogical activity. The action of this component permeates the various facets of professional activity both perception, imagination, and creativity.

The novelty, originality of the presented material is to determine the essence, content and structure of artistic and axiological culture as a necessary component of the professional training of a teacher of music art.

The significance of the research results is to outline the ways of further development of the theory and practice of art education of future teachers.

Keywords: music teacher; artistic and axiological culture; artistic activity; pedagogical activity.

\section{References}

1. Guly`ga A. B., Andreeva Y`. S. Эstety`ka v svete aksy`ology`y`. 50 let na Volxonke. SPb.: Aletejya, 2000. 445 s. [in Russian]

2. Hushchyna, H. A. Aksyolohycheskye aspektы otechestvennoho obrazovanyia kak faktor formyrovanyia professyonalno-tsennostnыkh oryentatsyi budushcheho uchytelia: dys. ... kand. ped. nauk, 2004. 188 s. [in Russian]

3. Elahyna V.S. Aksyolohycheskyi podkhod k razvytyiu yndyvydualnosty lychnosty studenta. URL: http://cyberleninka.ru/aksiologicgeskiy-podhod-k-razvitiyu-individualnosti-lichnostistudenta.pdf [in Russian]

4. Erasov, B.S. Sotsyalnaia kulturolohyia: uchebnyk dlia vuzov. 3-e yzd., dop. y pererab. M.: AspektPress, 2000. 591 s. [in Russian]

5. Esypova E.V. Kulturolohycheskye osnovы formyrovanyia tsennostnoho otnoshenyia k pedahohycheskoi professyy: avtoref. dys. ... kand. ped. Nauk. Rostov-na-Donu, 2007. 22 s. [in Russian] 
6. Kaliuzhnaia T. H. Aksyolohycheskyi podkhod v systeme professyonalno-pedahohycheskoi podhotovky budushcheho uchytelia. URL: http://lib.iitta.gov.ua/5180/1/ [in Russian]

7. Mukhyn A. S. Aksyolohyia yskusstva: k voprosu o bazovukh pryntsypakh. Studia culturae: Almanakh kafedru kulturolohyy y Tsentra yzuchenyia kulturb fylosofskoho fakulteta SPbHU; Vypusk 13 / otv. red. Y. Yu. Laryonov. - Sankt-Peterburh: Sankt-Peterburhskoe fylosofskoe obshchestvo, 2011. S. 61-76. ISSN 2225-3211. [in Russian]

8. Marchuk M. H. Tsinnisni potentsii znannia. Chernivtsi: Ruta, 2001. 319 s. [in Ukrainian]

9. Pliusnyn Yu. M. Dva poliusa tsennostnoho razvytyia lychnosty. Humanytarnbe nauky v Sybyry. 1995. № 2. S. 33-40. [in Russian]

10. Slastenyn V.A. Vvedenye v pedahohycheskuiu aksyolohyiu: [ucheb. pomoshch dlia stud. vyssh. ped. ucheb. zavedenyi]. M.: Yzdatelskyi tsentr "Akademyia", 2003. 192 s. [in Russian]

11. Smotrytskyi E.Iu. Skhemы po fylosofyy: Эtyka. Aksyolohyia. Myrovozzrenye / E.Iu. Smotrytskyi. Dnepropetrovsk: Porohy, 2003. 22 s. [in Russian]

12. Tkachova N.O. Aksiolohichnyi pidkhid do orhanizatsii pedahohichnoho protsesu v zahalnoosvitnomu navchalnomu zakladi: [monohrafiia]. Luhansk: LNPU imeni T.H. Shevchenka; Kh.: Vydavnytstvo "Karavella", 2006. 300 s. [in Ukrainian]

13. Iaroshenko A. O. Tsinnisnyi dyskurs osvity: [monohrafyia]. K.: NPU imeni M. P. Dragomanova, 2004. 156 s. [in Ukrainian]

14. Kiper H. Interkulturelle Erziehung in Praxis und Theorie. Saarbrücken, 1995.320 S.

15. Kluckhohn, C. Values and Value Orientation in the Theory of Actions. Parnsons T., Shils E. (eds.). Toward general Theory of Action. Cambridge. 1951. - $411 \mathrm{p}$.

16. Linden, B. Die Hochschule als multikulturelles Zentrum Bildung und Wissenschaft. 1996. №2. S. $16-17$

17. Pankiv L. Formation of Artstic Orientations of Senior Pupils in the Context of Modern Methodological Approaches Intellectual Archive, Volume 8, Number 3. - July - September 2019 (Canada). P. 198-206. // DOI 10.32370/IA_2019_09_23

About the author:

Hu Tinting, postgraduate student at the Faculty of Arts, National Pedagogical Dragomanov University (01054 Kyiv, Ukraine); ORCID: 0000-0002-2785-671X, hu.tintin2020@ gmail.com 